\title{
A comparative study on heavy metal content of plants irrigated with tap and wastewater
}

\author{
F. Zojaji • A. H. Hassani • M. H. Sayadi
}

Received: 14 February 2014/Revised: 15 July 2014/ Accepted: 22 October 2014/Published online: 5 December 2014

(C) Islamic Azad University (IAU) 2014

\begin{abstract}
The objective of the present study was to compare the potential accumulation capacity of $\mathrm{Cr}, \mathrm{Cu}$ and $\mathrm{Zn}$ in Zea mays and Populus deltoides Marsh. The study was conducted in an area in a wastewater treatment plant in Birjand for a period of 120 days. The soil sample and selected parts of Z. mays and P. deltoides Marsh were collected monthly and treated with hydrochloric acid and nitric acid. The results showed that the highest mean concentrations of $\mathrm{Cu}\left(1.78 \pm 0.93 \mathrm{mg} \mathrm{kg}^{-1}\right)$ and $\mathrm{Zn}$ $\left(2.65 \pm 1.37 \mathrm{mg} \mathrm{kg}^{-1}\right)$ were observed at $Z$. mays in September. The results indicated that the concentrations of $\mathrm{Cu}$ and $\mathrm{Zn}$ in $\mathrm{Z}$. mays and P. deltoides Marsh shoots irrigated with wastewater were higher than tap water. In addition, both the plants comparatively showed a significant increase in total metal amount when treated with wastewater $(p<0.001)$. The study of BCF and TF demonstrated that Z. mays was suitable for phytoextraction of $\mathrm{Cu}$, but unsuitable for both phytoextraction and phytostabilization of $\mathrm{Zn}$ and $\mathrm{Cr}$, whereas $P$. deltoides Marsh was unsuitable for both phytoextraction and phytostabilization of $\mathrm{Zn}, \mathrm{Cu}$ and $\mathrm{Cr}$.
\end{abstract}

Keywords Zea mays - Populus deltoides Marsh . Phytoextraction · Phytostabilization

F. Zojaji $(\bowtie) \cdot$ A. H. Hassani

Department of Environmental Science, Faculty of Environment and Energy, Science and Research Branch, Islamic Azad

University, Tehran, Iran

e-mail: fz60es@yahoo.com

M. H. Sayadi

Environmental Sciences Department, University of Birjand, Birjand, Iran

\section{Introduction}

Phytoremediation is the utilization of vegetation to remove, replace, stabilize and decrease pollutants in soil, sediment and water (Padmavathiamma and Loretta 2007). The most essential reasons for successful phytoremediation utilization are the site conditions, anticipated land use and the types of plants (Thangavel and Subhuram 2004).

Large volume of water is being consumed in farming, industry, domestic and civic usage. Agriculture is the largest user of freshwater in the world (Sayadi et al. 2010; Sayyed and Sayadi 2011). Usage of wastewater for irrigation in agricultural activities causes the biomagnification and accumulation of heavy metals in food chain (Akpor and Muchie 2010; Sayadi and Rezaei 2014). At the present scenario, the main challenge is how to handle the waste which is released at a faster rate as compared to its suitable removal (Madyiwa et al. 2002). Harvest irrigation by wastewater increases concerns about the safety of vegetables because their heavy metal content is increased $(\mathrm{Mu}-$ chuweti et al. 2006; Zojaji et al. 2014). Cu causes several physiological processes in florae, including photosynthesis, respiration, carbohydrate spreading, nitrogen and cell wall metabolism, seed production and disease resistance. Moreover, the higher concentration may cause to reduction of root growth and leaf chlorosis (Shabani and Sayadi 2012).

$\mathrm{Cr}$ not only weakens enzyme performance and plant growth, but also leads to chlorosis, membrane and root damage (Khan et al. 2006). According to Cardwell et al. (2002), aquatic plants have been widely utilized to clean polluted waters. In that research, copper, cadmium, lead and zinc were selected as the metals for the study because the existence of cadmium above trace levels in the environment is an indicator of pollution and lead is a common 
contaminant from road runoff. Zinc is a common metal existing in variable amounts and, if found in significant amounts, can be an indicator of industrial pollution. Moreover, copper is an indicator of industrial contamination of urban waters.

Ebbs and Kochian (1997) considered the poisonousness of $\mathrm{Zn}$ and $\mathrm{Cu}$ in three species from Brassica genus, viz. $B$. juncea, B. rapa and B. napus. They reported that Brassica species were more effective at removing zinc from nutrient solution than $\mathrm{Cu}$. Besides, the quantity of $\mathrm{Zn}$ and $\mathrm{Cu}$ removal was reduced when both metals were present. Ciura et al. (2005) explored the possibility of using common crops (red beet, field pumpkin, chicory, common bean, barley, white cabbage, maize, alfalfa, common parsnip) to remove heavy metals from the soil. They suggested that the most effective crop in the extraction of $\mathrm{Cd}, \mathrm{Mn}, \mathrm{Cu}, \mathrm{Ni}, \mathrm{Pb}$ and $\mathrm{Zn}$ was pumpkin. Likewise, most effective crops in $\mathrm{Cr}$ and $\mathrm{Fe}$ extractions were maize and alfalfa, respectively. The main objective of this study was a comparative accumulation capacity of $\mathrm{Cr}, \mathrm{Cu}$ and $\mathrm{Zn}$ in Zea mays and Populus deltoides Marsh cultivated on contaminated sites. The research was carried out in an area of wastewater treatment plant in the city of Birjand in 2012.

\section{Materials and methods}

Zea mays and P. deltoides Marsh were cultured in two separate areas constituting a total area of $4 \mathrm{~m}^{2}$. The experimental plants were irrigated with tap water and wastewater for 4 subsequent months, viz. August to November 2011. The irrigation was carried until it reached the field capacity. Five grams of samples of the root, stem and leaf of $Z$. mays and $P$. deltoides Marsh were assembled once a month. The collected samples were washed with distilled water, dried, and ashed in an oven at $600{ }^{\circ} \mathrm{C}$ for $6 \mathrm{~h}$. Triplicate sets of dehydrated samples were broken down with $5 \mathrm{cc}$ acid, and volume of the watery digested samples were made up to $25 \mathrm{ml}$ (Schmidt 2003). $0.5 \mathrm{~kg}$ soil samples of soil at $0-30 \mathrm{~cm}$ depth were collected in triplicate sets and combined. To achieve the bio-available concentration of the metals, the soil samples were dried at $105{ }^{\circ} \mathrm{C}$ and filtered through a $2-\mathrm{mm}$ sieve. Then, $2 \mathrm{~g}$ soil samples were mixed with $5 \mathrm{ml}$ of hydrogen peroxide $(30 \%)$ and digested at room temperature for $1 \mathrm{~h}$ with occasional shaking. A second $5 \mathrm{ml}$ aliquot of hydrogen peroxide was introduced into and digested at $85{ }^{\circ} \mathrm{C}$ (water bath) for $1 \mathrm{~h}$. The contents were evaporated to a small volume $(1-2 \mathrm{ml})$. Twenty-five milliliters of ammonium acetate $(0.1 \mathrm{ml} / \mathrm{l}$, adjusted to $\mathrm{pH} 2$ with nitric acid) was added to the cool and moist residue. The volume of the watery digested samples was made up to $25 \mathrm{ml}$ and introduced into the water bath for $12 \mathrm{~h}$ (Radojevic and
Bashkin 1999). The digested samples were assessed in the Water and Wastewater Company, South Khorasan, using AA-7000 series of atomic absorption (Shimadzu) by flame mode, and concentration of $\mathrm{Zn}, \mathrm{Cr}$ and $\mathrm{Cu}$ was evaluated. The transfer factor is the motion of a heavy metal from the root to the aerial parts (stem and leaves), which was assessed using the subsequent formula (Kim et al. 2003):

$$
\mathrm{TF}=\frac{\text { Element of Shoots }(\text { stem and leaves })\left(\mathrm{mg} \mathrm{kg}^{-1}\right)}{\text { Element of root } \mathrm{m} \mathrm{kg}^{-1}} \times 100
$$

$\mathrm{TF}<1$ indicate that the metals are stored in the roots of a plant, and $\mathrm{TF}>1$ shows translocation of metals to the shoots of plants. Metal uptake is also referred as a bioconcentration factor (BCF). It illustrates the capability of a plant to accumulate a specific metal from the soil substrate (Zayed et al. 1998). It was calculated as follows:

$$
\mathrm{BCF}=\frac{\text { Average Heavy Metal concentration in root }\left(\mathrm{mg} \mathrm{kg}^{-1}\right)}{\text { Heavy Metal added in soil }\left(\mathrm{mg} \mathrm{kg}^{-1}\right)}
$$

The zero BCF value implies limited movement of metals from sediment to a plant. The higher BCF value is more suitable for phytoextraction (Blaylock et al. 1997). However, BCF $>2$ relates a high value. Nevertheless, a change in $\mathrm{BCF}$ is related to the individual plant biomass and soil elemental focus, and the productivity of BCF is better understood when it is compared between different plant species or elements.

According to Yanqun et al. (2005), enrichment factor (EF) is defined as the concentration of heavy metals in plant shoots divided by the heavy metal concentration in soil, whereas Khan et al. (2006) reported that enrichment coefficient depends on the soluble portion of metals and organic matters in soils:

$\mathrm{EF}=\frac{\text { Average Heavy Metal concentration in shoot }\left(\mathrm{mg} \mathrm{kg}^{-1}\right)}{\text { Heavy Metal concentration in soil }\left(\mathrm{mg} \mathrm{kg}^{-1}\right)}$

Statistical analysis

All experiments were carried out in triplicate, and significant differences were analyzed by ANOVA (Mann-Whitney, $U$ test due to nonparametric data) using SPSS software.

\section{Results and discussion}

$\mathrm{Cr}, \mathrm{Cu}$ and $\mathrm{Zn}$ concentrations in soils

The wastewater treatment plot was composed of sand (39\%), silt (48\%) and clay (13\%). The concentration of $\mathrm{Cr}$ in soils irrigated with wastewater and tap water was 2.146 and $2.005 \mathrm{mg} \mathrm{kg}^{-1}$, respectively. The $\mathrm{Cu}$ 
Table 1 Concentration of $\mathrm{Cr}, \mathrm{Cu}$ and $\mathrm{Zn}$ in different parts of Zea mays and Populus deltoides Marsh $\left(\mathrm{mg} \mathrm{kg}^{-1}\right)$

\begin{tabular}{|c|c|c|c|c|c|c|c|c|c|c|c|c|c|c|}
\hline \multirow[t]{2}{*}{ Plant } & \multirow[t]{2}{*}{ Treatment } & \multirow[t]{2}{*}{ Portion of plant } & \multicolumn{3}{|c|}{ November } & \multicolumn{3}{|c|}{ October } & \multicolumn{3}{|c|}{ September } & \multicolumn{3}{|c|}{ August } \\
\hline & & & $\mathrm{Zn}$ & $\mathrm{Cu}$ & $\mathrm{Cr}$ & $\mathrm{Zn}$ & $\mathrm{Cu}$ & $\mathrm{Cr}$ & $\mathrm{Zn}$ & $\mathrm{Cu}$ & $\mathrm{Cr}$ & $\mathrm{Zn}$ & $\mathrm{Cu}$ & $\mathrm{Cr}$ \\
\hline \multirow[t]{10}{*}{ Zea mays } & \multirow[t]{3}{*}{ Tap water } & Root & 1.69 & 1.13 & 2.37 & 2.64 & 1.65 & 2.21 & 4.27 & 1.6 & 2.12 & 3.28 & 0.9 & 1.13 \\
\hline & & Stem & 1.22 & 1.41 & 0.16 & 1.01 & 1.51 & 0.2 & 2.24 & 1.2 & 0.18 & 1.68 & 0.75 & 0.26 \\
\hline & & Leaves & 0.62 & 0.44 & 0.24 & 1.49 & 0.76 & 0.22 & 0.8 & 0.87 & 0.14 & 0.58 & 0.61 & 0.17 \\
\hline & \multirow[t]{7}{*}{ Wastewater } & Root & 1.74 & 1.15 & 2.54 & 2.69 & 1.67 & 2.47 & 4.27 & 2.12 & 2.12 & 3.28 & 2.87 & 1.37 \\
\hline & & Stem & 1.34 & 1.48 & 0.36 & 1.06 & 1.68 & 0.3 & 2.26 & 1.44 & 0.29 & 1.77 & 1.37 & 0.28 \\
\hline & & Leaves & 0.69 & 1.47 & 0.42 & 1.6 & 1.84 & 0.38 & 2.03 & 3.47 & 0.35 & 4.38 & 3.28 & 0.33 \\
\hline & & Mean & 1.22 & 1.18 & 1.02 & 1.75 & 1.52 & 0.96 & 2.65 & 1.78 & 0.87 & 2.50 & 1.63 & 0.59 \\
\hline & & Max & 1.74 & 1.48 & 2.54 & 2.69 & 1.84 & 2.47 & 4.27 & 3.47 & 2.12 & 4.38 & 3.28 & 1.37 \\
\hline & & Min & 0.62 & 0.44 & 0.16 & 1.01 & 0.76 & 0.20 & 0.80 & 0.87 & 0.14 & 0.58 & 0.61 & 0.17 \\
\hline & & SD & 0.48 & 0.39 & 1.12 & 0.75 & 0.39 & 1.07 & 1.37 & 0.93 & 0.97 & 1.39 & 1.16 & 0.52 \\
\hline \multirow[t]{10}{*}{ Populus deltoides Marsh } & \multirow[t]{3}{*}{ Tap water } & Root & 1.28 & 0.59 & 0.54 & 1.79 & 0.32 & 0.44 & 1.51 & 2.15 & 0.24 & 1.45 & 1.45 & 0.69 \\
\hline & & Stem & 1.69 & 0.59 & 0.13 & 2.13 & 0.39 & 0.14 & 1.71 & 1.77 & 0.16 & 1.91 & 1.32 & 0.15 \\
\hline & & Leaves & 1.15 & 0.45 & 0.2 & 1.19 & 0.37 & 0.21 & 0.95 & 0.51 & 0.18 & 1.26 & 0.22 & 0.18 \\
\hline & \multirow[t]{7}{*}{ Wastewater } & Root & 1.38 & 0.63 & 0.57 & 1.8 & 0.38 & 0.54 & 1.62 & 2.15 & 0.57 & 2.43 & 1.58 & 0.76 \\
\hline & & Stem & 2.37 & 0.68 & 0.15 & 3.41 & 0.55 & 0.15 & 2.9 & 1.99 & 0.16 & 4.36 & 1.49 & 0.22 \\
\hline & & Leaves & 1.44 & 0.55 & 0.26 & 1.26 & 0.43 & 0.22 & 1.38 & 0.56 & 0.2 & 1.34 & 0.38 & 0.19 \\
\hline & & Mean & 1.55 & 0.58 & 0.31 & 1.93 & 0.41 & 0.28 & 1.68 & 1.52 & 0.25 & 2.13 & 1.07 & 0.37 \\
\hline & & Max & 2.37 & 0.68 & 0.57 & 3.41 & 0.55 & 0.54 & 2.90 & 2.15 & 0.57 & 4.36 & 1.58 & 0.76 \\
\hline & & Min & 1.15 & 0.45 & 0.13 & 1.19 & 0.32 & 0.14 & 0.95 & 0.51 & 0.16 & 1.26 & 0.22 & 0.15 \\
\hline & & SD & 0.44 & 0.08 & 0.20 & 0.81 & 0.08 & 0.17 & 0.65 & 0.78 & 0.16 & 1.18 & 0.61 & 0.28 \\
\hline
\end{tabular}

concentration in soils irrigated with wastewater and tap water was 1.23 and $0.899 \mathrm{mg} \mathrm{kg}^{-1}$, respectively. Furthermore, $\mathrm{Zn}$ concentration in soils irrigated with wastewater and tap water was 4.16 and $2.54 \mathrm{mg} \mathrm{kg}^{-1}$, respectively.

$\mathrm{Cr}, \mathrm{Cu}$ and $\mathrm{Zn}$ concentrations in wastewater and tap water

The concentration of $\mathrm{Cr}$ in wastewater that is provided from wastewater treatment plant of Birjand City and tap water was 12 and $5 \mathrm{mg} \mathrm{l}^{-1}$, respectively. In addition, the concentrations of $\mathrm{Cu}$ and $\mathrm{Zn}$ in wastewater and tap water were 6.5 and 2 and 48.2 and $21.35 \mathrm{mg} \mathrm{l}^{-1}$, respectively.

\section{Concentrations of $\mathrm{Cr}, \mathrm{Cu}$ and $\mathrm{Zn}$ in the plants}

The results of the present study showed that the average concentrations of $\mathrm{Cr}$ in the roots of $Z$. mays and P. deltoides Marsh irrigated with wastewater and tap water were 2.13 and 1.96 and 0.61 and $0.48 \mathrm{mg} \mathrm{kg}^{-1}$, respectively. The average concentrations of $\mathrm{Cu}$ in the roots of $Z$. mays and $P$. deltoides Marsh irrigated with wastewater and tap water were 1.95 and 1.32 and 1.19 and $1.13 \mathrm{mg} \mathrm{kg}^{-1}$, respectively. And the average concentrations of $\mathrm{Zn}$ in the roots of $Z$. mays and $P$. deltoides Marsh irrigated with wastewater and tap water were 3.00 and 2.97 and 1.81 and $1.51 \mathrm{mg} \mathrm{kg}^{-1}$, respectively.
The highest $\mathrm{Cr}$ concentration was measured in the root of Z. mays $\left(2.54 \mathrm{mg} \mathrm{kg}^{-1}\right)$ treated with wastewater in November, while the lowest $\mathrm{Cr}$ concentration was detected in the stem of $P$. deltoides Marsh $\left(0.13 \mathrm{mg} \mathrm{kg}^{-1}\right)$. Comparatively, the concentrations of $\mathrm{Cr}$ in shoots and roots of $Z$. mays and $P$. deltoides Marsh irrigated with wastewater were higher than those of the plants irrigated with tap water (Table 1).

The highest $\mathrm{Cu}$ concentration was measured in the sample of $Z$. mays $\left(3.47 \mathrm{mg} \mathrm{kg}^{-1}\right.$ in leaves), while the lowest concentration was detected in the sample of $P$. deltoides Marsh (0.22 $\mathrm{mg} \mathrm{kg}^{-1}$ in leaves). The concentrations of $\mathrm{Cu}$ in $Z$. mays and P. deltoides Marsh shoots irrigated with wastewater were comparatively higher in plants irrigated with tap water (Table 1).

The highest $\mathrm{Zn}$ concentration was measured in the sample of $Z$. mays (4.38 $\mathrm{mg} \mathrm{kg}^{-1}$ in leaves), while the lowest concentration was detected in the sample of $P$. deltoides Marsh (0.58 $\mathrm{mg} \mathrm{kg}^{-1}$ in leaves). The concentrations of $\mathrm{Zn}$ in Z. mays and P. deltoides Marsh shoots irrigated with wastewater were higher than those in plants irrigated with tap water (Table 1).

Metal concentration in the treatments

Total $\mathrm{Cr}, \mathrm{Cu}$ and $\mathrm{Zn}$ concentrations were measured in varied parts of each plant at the tap water and wastewater 


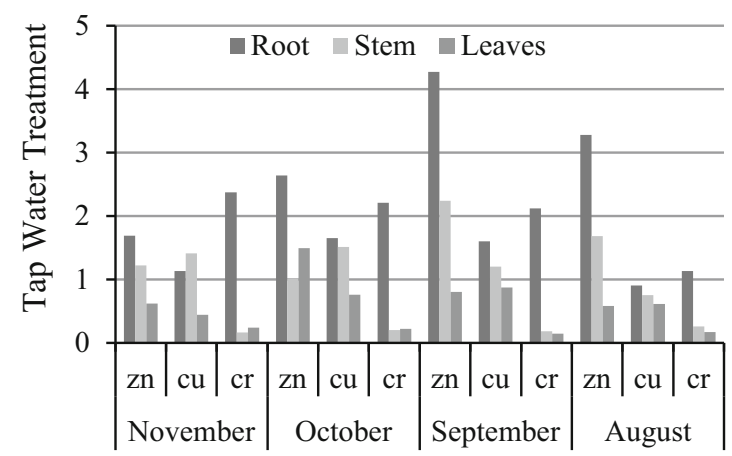

Metals extraction by Zea Mays $(\mathrm{mg} / \mathrm{kg})$

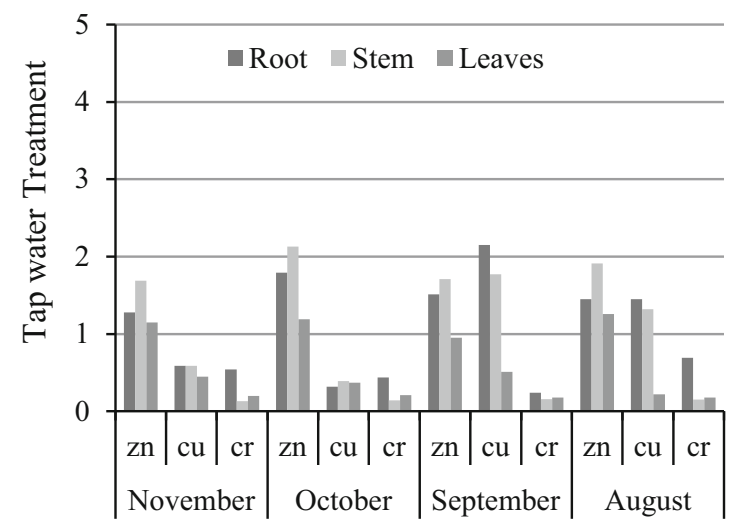

Metals extraction by Populusdeltoides Marsh $(\mathrm{mg} / \mathrm{kg})$

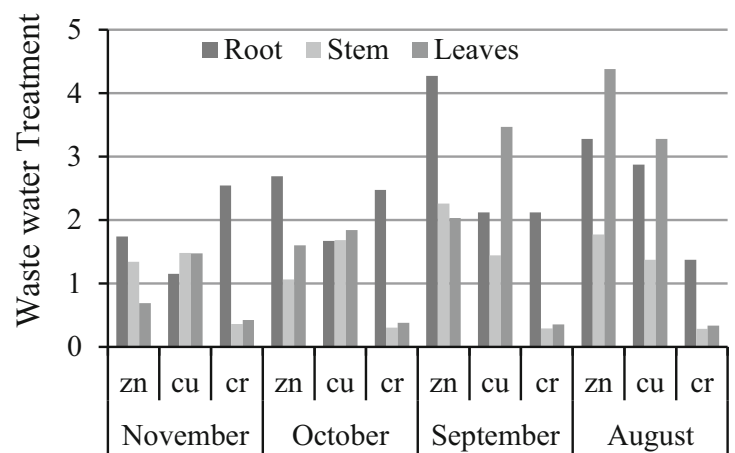

Metals extraction by Zea Mays $(\mathrm{mg} / \mathrm{kg})$

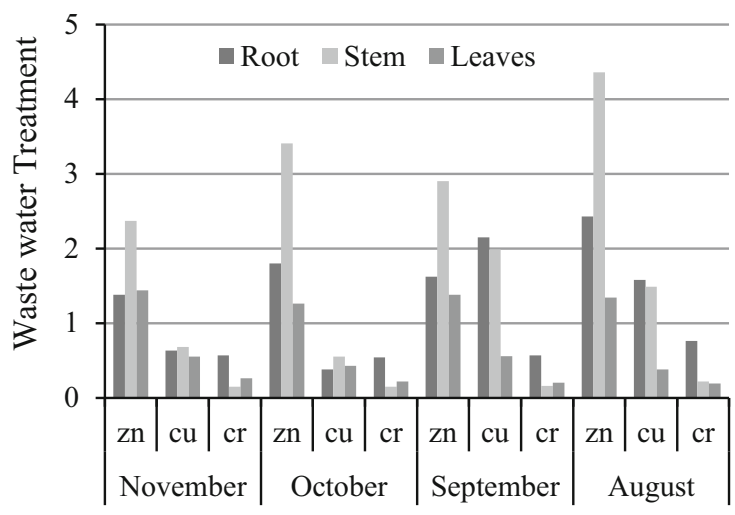

Metals extraction by Populusdeltoides Marsh $(\mathrm{mg} / \mathrm{kg})$

Fig. 1 Comparison of metal accumulation in root, stem and leaves of Zea mays and Populus deltoides Marsh treated for 4 successive months with tap water and wastewater, respectively

treatments. Comparative metal accumulation in the root, stem and leaves of $Z$. mays and $P$. deltoides Marsh for 4 successive months treated with tap water and wastewater treatment is presented in the Fig. 1. With few exceptions, the higher metal concentration was observed in the roots of $Z$. mays, whereas in $P$. deltoides Marsh, higher metal concentration was observed in stems (Fig. 1). The two plants showed a significant increase in total metal content in the wastewater treatment as compared to the tap water treatment plot $(p<0.001)$. As far as, the metal concentration in roots, stems and leaves is concerned, it exhibited a significant difference between the two experimental plants $(p<0.05)$.

\section{$\mathrm{Cr}, \mathrm{Cu}$ and $\mathrm{Zn}$ translocation factor (root/shoot)}

The translocation ability of these heavy metals in $Z$. mays was in the following order: $\mathrm{Cu}(2.06)>\mathrm{Zn}(1.26)>\mathrm{Cr}$ (0.31), while the translocation ability of these heavy metals in $P$. deltoides Marsh was $\mathrm{Zn} \mathrm{(2.55)}>\mathrm{Cu}(1.39)>\mathrm{Cr}$ (0.64). Metals that are absorbed by plants and mostly stored in the roots of plants are indicated by TF value $<1$. The translocation value $>1$ indicates translocation to the shoots of a plant. In the present study, translocation value $>1$ for $\mathrm{Zn}$ and $\mathrm{Cu}$ were found in $Z$. mays and $P$. deltoides Marsh, while translocation values for $\mathrm{Cr}$ in the $Z$. mays and $P$. deltoides Marsh were $<1$ (Fig. 2). TF higher than 1 indicated an effective ability to transport metal from root to leaf, most probably via an efficacious metal transporter system of plants (Zhao et al. 2002). It could be even sequestration of metals in leaf vacuoles and apoplast (Lasat et al. 2000). Translocation factor is an indication of the plant capability to translocate metal from roots to the aerial parts (Marchiol et al. 2004). As indicated in Fig. 1, it can be assumed that these metals $(\mathrm{Zn}$ and $\mathrm{Cu})$ are transported to the aerial parts of the plant, while $\mathrm{Cr}$ are stored in the roots. Yanqun et al. (2005) stated that species with $\mathrm{TF}<1$ were excluder species. Thus, it can be expected that Z. mays and $P$. deltoides Marsh are excluder species for Cr. Comparative study of TF in Z. mays and P. deltoides Marsh indicated that translocation factor of $\mathrm{Zn}$ and $\mathrm{Cr}$ in $P$. deltoides Marsh is greater than that in Z. mays, whereas TF of $\mathrm{Cu}$ in $Z$. mays is greater than that in P. deltoides Marsh (Fig. 1). Figure 1 shows that $P$. deltoides Marsh had a greater transport of $\mathrm{Zn}$ and $\mathrm{Cr}$ from root to shoot in comparison to Z. mays, while $Z$. mays exhibited a greater transport of $\mathrm{Cu}$ 


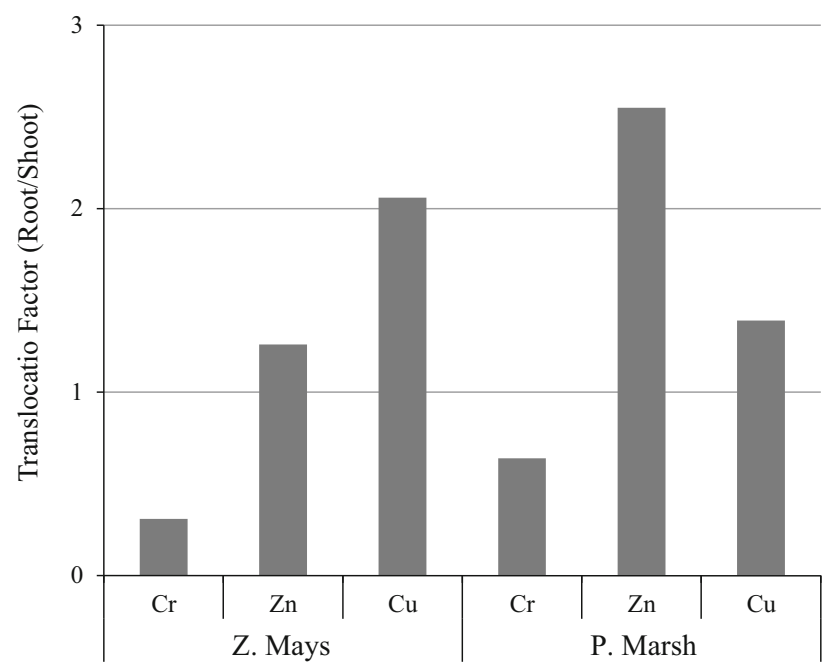

Fig. 2 Translocation factor of $\mathrm{Cr}, \mathrm{Cu}$ and $\mathrm{Zn}$ in Zea mays and Populus deltoides Marsh

from root to shoot in comparison to $P$. deltoides Marsh. It is interesting to note that the maximum transport was determined in $P$. deltoides Marsh for $\mathrm{Zn}$ and that the minimum transport was detected in $Z$. mays for $\mathrm{Cr}$.

\section{$\mathrm{Cr}, \mathrm{Cu}$ and $\mathrm{Zn}$ bio-concentration factor}

Figure 3 shows the BCF movement of each metal from soil to $Z$. mays and P. deltoides Marsh plants. However, zero $\mathrm{BCF}$ value implies limited movement from the soil to the plant. BCF value of $Z$. mays at the root was highest for $\mathrm{Cu}$ (1.58) followed by $\mathrm{Cr}(0.99)$ and $\mathrm{Zn}(0.72)$, while the stem and leaf values were in the following order $\mathrm{Cu}>\mathrm{Zn}>\mathrm{Cr}$. The BCF of $Z$. mays for $\mathrm{Zn}$ and $\mathrm{Cr}$ in root, stem and leaf showed low value $<1$, and BCF of $P$. deltoides Marsh for $\mathrm{Zn}, \mathrm{Cu}$ and $\mathrm{Cr}$ in root, stem and leaf showed low value $<1$ (Fig. 3).Thus, this indicated a limited movement of metals from soil to the plant. According to Ghosh and Singh (2005), BCF is an index of plant capability to accumulate a particular metal with respect to its concentration in the sediment. The BCF of $\mathrm{Z}$. mays for $\mathrm{Cu}$ in root and stem was $>1$. The BCF value $>1$ showed that plant is suitable for phytoextraction (Blaylock et al. 1997).

Plants with both $\mathrm{BCF}$ and translocation factor greater than one (TF and $\mathrm{BCF}>1$ ) have the potential to be utilized in phytoextraction, whereas plants with $\mathrm{BCF}>1$ and $\mathrm{TF}<1$ have the potential for phytostabilization (Yoon et al. 2006).

The results of the present study revealed that $Z$. mays is suitable for phytoextraction of $\mathrm{Cu}$ and is unsuitable for both phytoextraction and phytostabilization of $\mathrm{Zn}$ and $\mathrm{Cr}$. Additionally, $P$. deltoides Marsh is unsuitable for both phytoextraction and phytostabilization of $\mathrm{Zn}, \mathrm{Cu}$ and $\mathrm{Cr}$.

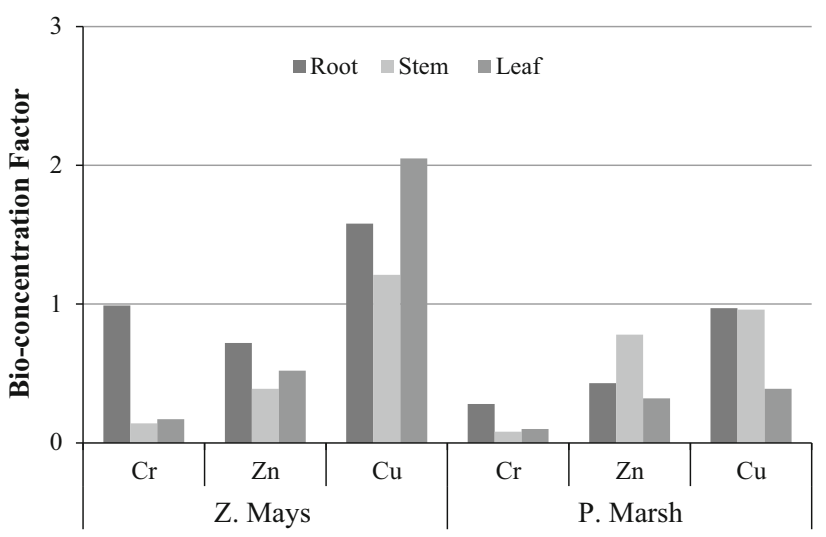

Fig. 3 Bio-concentration factor in the root, stem and leaf of Zea mays and Populus deltoides Marsh

\section{$\mathrm{Cr}, \mathrm{Cu}$ and $\mathrm{Zn}$ enrichment coefficient (EC)}

Enrichment coefficient is indicating phytoremediation of species (Zhao et al. 2003). Both EF and TF have to be measured in order to evaluate whether a particular plant is a metal hyperaccumulator or not. Therefore, a hyperaccumulator plant should have $\mathrm{EF}>1$ and $\mathrm{TF}>11$, and a total accumulation $>1,000 \mathrm{mg} \mathrm{kg}^{-1}$ of $\mathrm{Cu}, \mathrm{Cr}, \mathrm{Co}, \mathrm{Ni}$ or $\mathrm{Pb}$ and/or $>10,000 \mathrm{mg} \mathrm{kg}^{-1}$ of Fe, Mn or Zn (Ma et al. 2001). In this study, the enrichment coefficient of $\mathrm{Cu}$ in $Z$. mays was $>1.0$, while EC of $\mathrm{Cr}$ and $\mathrm{Zn}$ was $<1.0$ (Table 2). Moreover, $\mathrm{EF}$ of $\mathrm{Cu}$ and $\mathrm{Zn}$ in $P$. deltoides Marsh was $>1.0$, and $\mathrm{EF}$ of $\mathrm{Cr}$ was $<1.0$. Therefore, it can be safely said that $Z$. mays can be regarded as a hyperaccumulator of $\mathrm{Cu}$, while $P$. deltoides Marsh can be regarded as a hyperaccumulator of $\mathrm{Cu}$ and $\mathrm{Zn}$.

\section{Conclusion}

The identifications of plants play a key role in phytoremediation for management of contaminated soil and water. This study was conducted in an area integrated with natural conditions where the effect of soil buffering capacity influenced nutrient accessibility to a plant. Though the $\mathrm{Cr}, \mathrm{Cu}$ and $\mathrm{Zn}$ uptake and transfer to the different parts of a plant are not exactly understood, but the behavior of the plant remains fairly consistent across the site. In the present study, both the experimental plants showed a significant increase in total metal amount when treated with the wastewater as compared to the tap water treatment $(p<0.001)$. Besides, the study of BCF and TF demonstrated that $Z$. mays was suitable for phytoextraction of $\mathrm{Cu}$ and unsuitable for both phytoextraction and phytostabilization of $\mathrm{Zn}$ and $\mathrm{Cr}$, whereas $P$. deltoides Marsh was unsuitable for both phytoextraction and phytostabilization 
Table 2 Enrichment coefficient of $\mathrm{Cr}, \mathrm{Cu}$ and $\mathrm{Zn}$ in Zea mays and Populus deltoides

\begin{tabular}{lll}
\hline Heavy metals & \multicolumn{2}{l}{ Plant } \\
\cline { 2 - 3 } & Z. mays & P. deltoides \\
\hline $\mathrm{Cr}$ & 0.31 & 0.18 \\
$\mathrm{Cu}$ & 3.26 & 1.35 \\
$\mathrm{Zn}$ & 0.91 & 1.11 \\
\hline
\end{tabular}

of $\mathrm{Zn}, \mathrm{Cu}$ and $\mathrm{Cr}$. The study of $\mathrm{EF}$ and $\mathrm{TF}$ indices showed that $Z$. mays can be regarded as a hyperaccumulator of $\mathrm{Cu}$ and that $P$. deltoides Marsh can be considered as a hyperaccumulator of both $\mathrm{Cu}$ and $\mathrm{Zn}$. Thus, it could be safely concluded that biomass production, growth rate and soil characteristics, etc. strongly influenced phytoremediation, and therefore, further studies on these experimental plants are highly suggested.

Acknowledgment The authors are grateful to the authorities of Science and Research Branch Islamic Azad University for their help and providing the funding needed for this research. The reviewers are also appreciated for their constructive criticisms. We would also like to thank Dr. Mrs. Mahavash F. Kavian for English editing of the paper.

\section{References}

Akpor OB, Muchie M (2010) Remediation of heavy metals in drinking water and wastewater treatment systems, processes and applications. Int J Phys Sci 51:1807-1817

Blaylock MJ, Salt DE, Dushenkov S, Zakharove O, Gussman C, Kapulnik Y (1997) Enhanced accumulation of $\mathrm{Pb}$ in Indian mustard by soil, applied chelating agents. Environ Sci Technol 31:860-865

Cardwell AJ, Hawker DW, Greenway M (2002) Metal accumulation in aquatic macrophytes from southeast Queensland, Australia. Chemosphere 48:653-663

Ciura J, Poniedzia EM, Sêkara A, Jê- Drszczyk E (2005) The possibility of using drops as metal phytoremediants. Pol J Environ Stud 14:17-37

Ebbs SD, Kochian LV (1997) Toxicity of zinc and copper to Brassica species: implication for phytoremediation. J Environ Qual 26:776-783

Ghosh M, Singh SP (2005) A comparative study of cadmium phytoextraction by accumulator and weed species. Environ Pollut 133:365-371

Khan S, Cao Q, Chen BD, Zhu YG (2006) Humic acids increase the phytoavailability of $\mathrm{Cd}$ and $\mathrm{Pb}$ to wheat plants cultivated in freshly spiked contaminated soil. J Soil Sediments 6(4):236-242

Kim LS, Kang KH, Green PJ et al. (2003) Investigation of metal accumulation in Polygonumthunbergii for phytoextraction. Environ Pollut 126(2):126-235
Lasat MM, Pence NS, Garvin DF, Ebbs SD, Kochian LV (2000) Molecular physiology of zinc transport in the Zn hyperaccumulator Thlaspi caerulescens. J Exp Bot 51:71-79

Ma LQ, Komar KM, Tu C, Zhang W, Cai Y, Kennelley ED (2001) A fern that hyperaccumulates arsenic. Nature 409:579

Madyiwa S, Chimbari M, Nyamangara J, Bangira C (2002) Cumulative effects of sewage sludge and effluent: mixture application on soil properties of a sandy soil under a mixture of star and kikuyu grasses in Zimbabwe. Phys Chem Earth 27:747-753

Marchiol L, Assolari S, Sacco P, Zebri G (2004) Phytoextraction of heavy metals by canola (Brassica napus) and radish (Raphanus sativus) grown on multi-contaminated soil. Environ Pollut 132:21-27

Muchuweti M, Birkett JW, Chinyanga E, Zvauya R, Scrimshaw MD, Lester JN (2006) Heavy metal content of vegetables irrigated with mixture of wastewater and sewage sludge in Zimbabwe: implications for human health. Agric Ecosyst Environ 112:41-48

Padmavathiamma PK, Loretta YLI (2007) Phytoremediation technology: hyper-accumulation metals in plants. Water Air Soil Pollut 184:105-126

Radojevic M, Bashkin VN (1999) Practical environmental analysis. Royal Society of Chemistry, Cambridge

Sayadi MH, Rezaei MR (2014) Impact of land use on the distribution of toxic metals in surface soils in Birjand city, Iran. Proc Int Acad Ecol Environ Sci 4(1):18-29

Sayadi MH, Sayyed MRG, Suyash K (2010) Short-term accumulative signatures' of heavy metal in river bed sediments, Tehran Iran. Environ Monit Assess 162:465-473

Sayyed MRG, Sayadi MH (2011) Variations in the heavy metal accumulations within the surface soils from the Chitgar industrial area of Tehran. Proc Int Acad Ecol Environ Sci 1(1):36-46

Schmidt U (2003) Enhancing phytoextraction: the effect of chemical soil manipulation on mobility, plant accumulation, and leaching of heavy metals. J Environ Qual 32:1939-1954

Shabani N, Sayadi MH (2012) Evaluation of heavy metals accumulation by two emergent macrophytes from the polluted soil: an experimental study. Environmentalist 32(1):91-98

Thangavel P, Subhuram CV (2004) Phytoextraction role of hyper accumulators in metal contaminated soils. Proc Indian Natl Sci Acad Part B 70(1):109-130

Yanqun Z, Yuan L, Jianjun C, Haiyan C, Li Q, Schvartz C (2005) Hyperaccumulation of $\mathrm{Pb}, \mathrm{Zn}$ and $\mathrm{Cd}$ in herbaceous grown on lead-zinc mining area in Yunnan, China. Environ Int 31:755-762

Yoon J, Cao X, Zhou Q, Lena QM (2006) Accumulation of Pb, Cu and $\mathrm{Zn}$ in native plants growing on a contaminated Florida site. Sci Total Environ 368:456-464

Zayed A, Gowthaman S, Terry N (1998) Phytoaccumulation of trace elements by wetland plants : I. Duckweed. J Environ Qual 27:715-721

Zhao FJ, Hamon RE, Lombi E, Mclaughlin MJ, McGrath SP (2002) Characteristics of cadmium uptake in two contrasting ecotypes of the hyperaccumulator Thlaspi caerulescens. J Exp Bot 53:535-543

Zhao FJ, Lombi E, McGrath SP (2003) Assessing the potential for zinc and cadmium phytoextraction with the hyperaccumulator Thlaspi caerulescens. Plant Soil 249:37-43

Zojaji F, Hassani AH, Sayadi MH (2014) Bioaccumulation of chromium by Zea mays in wastewater-irrigated soil: an experimental study. Proc Int Acad Ecol Environ Sci 4(2):62-67 